\title{
Potential of wild oregano essential oil in control of Monilinia rot on stored sweet cherry fruits
}

\author{
JELENA KALAJDŽIĆ ${ }^{1}$, BISERKA MILIĆ ${ }^{1}$, ALEKSANDRA STANKOV ${ }^{2}$, MLADEN \\ PETREŠํ, MILA GRAHOVAC $^{2}$, JELENA VUKOTIĆ ${ }^{2}$, VERA STOJŠIN ${ }^{2}$
}

${ }^{1}$ Department of Fruit growing, Viticulture, Horticulture and Landscape architecture, Faculty of Agriculture, Trg Dositeja Obradovića 8, Novi Sad 21000, Serbia

${ }^{2}$ Department of Plant and Environmental Protection, University of Novi Sad, Faculty of Agriculture, Trg Dositeja Obradovića 8, 21000 Novi Sad, Serbia

\begin{abstract}
Sweet cherry fruits are perishable goods, and the fruit quality can additionally be affected by fungal diseases, primarily by Monilinia species. A promising method for fungal disease control in storage is the use of essential oils. Three different methods of wild oregano essential oil application were tested: incorporation (5\% dilution), exposing to the vapor phase $(0.08$ and $0.16 \mu \mathrm{l} / \mathrm{cm} 3)$, and fruit immersion in $5 \%$ dilution. Incorporation of essential oil showed the strongest inhibitory effect on Monilinia laxa in both tested cultivars (Regina and Karina). The vapor phase had the same effect on inhibition of Monilinia laxa at both concentrations on cold-stored fruits of cv. Regina after incubation at room temperature, while on cv. Karina, higher concentration showed a stronger inhibitory effect. The immersion in EO dilution caused phytotoxic changes on the fruit skin. Necrosis development rates significantly increased after the cold storage period terminated.
\end{abstract}

Keywords Essential oil, sweet cherry, stored fruit rot, Monilinia laxa.

To cite this article: KALAJDŽIĆ J, MILIĆ B, STANKOV A, PETREŠ M, GRAHOVAC M, VUKOTIĆ J, STOJŠIN V. Potential of wild oregano essential oil in control of Monilinia rot on stored sweet cherry fruits. Rom Biotechnol Lett. 2021; 26(4): 2779-2787. DOI: $10.25083 / \mathrm{rbl} / 26.4 / 2779-2787$

*Corresponding author: JELENA KALAJDŽIĆ, Department of Fruit growing, Viticulture, Horticulture and Landscape architecture, Faculty of Agriculture, Trg Dositeja Obradovića 8, Novi Sad 21000, Serbia

E-mail: jelena.tarlanovic@polj.edu.rs $\quad$ Tel.: +381214853249 


\section{Introduction}

Sweet cherry is grown worldwide because it is an early season fruit with an excellent quality. However, its perishable nature is a limiting factor, fruits can be stored for a very short time, two to three weeks only (JIANG \& al [1]; DZIEDZIC \& al [2]). During storage, physiological disorders or diseases caused by phytopathogenic fungi can occur on the fruits and cause significant losses (BAL [3]). Losses caused by phytopathogenic fungi during storage period can reach up to $20-35 \%$ in developed countries (ZHU [4]), while in developing countries, these losses can be much higher (over 50\%) (JANISIEWITZ \& KORSTEN [5]). Monilinia spp. and Botrytis cinerea are the most important pathogens of sweet cherry fruits during storage (ROMANAZI \& al [6]; FELIZIANI \& al [7]). Infection with Monilinia spp. occurs during growing season, but the most significant losses caused by this pathogen occur during storage, handling, and shelf-life of sweet cherry fruits. Symptoms caused by Monilinia spp. appear as dark brown circular spots, which rapidly enlarge.Synthetic fungicides are the most effective way to protect fruits from diseases caused by phytopathogenic fungi. However, the excessive use of synthetic fungicides can lead to resistance development, and, consequently, fungicides may lose their efficacy (BRENT \& HOLLOMON [8]). Also, due to ecotoxicological properties, fungicide treatments after harvest are prohibited in most countries (SERRANO $\&$ al [9]). In order to prevent the occurrence of diseases caused by phytopathogenic fungi on fruits after harvest, ecofriendly alternative methods, such as physical treatments (JUNEJA \& THAYER [10]), naturally originated/derived substances (IPPOLITO \& NIGRO [11]) and biological control agents (JANISIEWITZ \& KORSTEN [5]) are becoming increasingly important.

Essential oils (EOs) are a complex mixture of highly volatile compounds with different mechanisms of action; therefore the risk of resistance occurrence to EO in treated microorganisms is reduced (DAFERERA \& al [12]). Antifungal activity of EOs is associated with the content of monoterpene phenols, particularly timol, carvacol and eugenol (BARRERA-NECHA \& al [13]). Although there are many studies regarding inhibitory effect of EOs on the growth and virulence of phytopathogenic fungi, there are only a few about EOs in planta applications, assessing the effects of different concentrations and application techniques. DAFERERA \& al [12] studied effects of wild oregano (Origanum vulgare), thyme (Thymus capitatus), lavender (Lavandula angustifolia), rosemary (Rosmarinus officinalis) and sage (Salvia fruticosa) on growth and virulence of phytopathogenic fungi Botrytis cinerea, Fusarium spp. and Clavibacter michigenensis subsp. michigenensis. EOs expressed different efficacy depending on their composition, applied concentration, as well as on species of phytopathogenic fungi (DAFERERA \& al [12]).

The aim of this study was to investigate the inhibitory effect of EO of wild oregano applied by incorporation, immersing fruits of sweet cherry in EO dilution and by exposing fruits to vapor phase, on the development of Monilinia laxa during and after the storage period.

\section{Materials and Methods}

\section{Fungal pathogens}

Monilinialaxa isolate was used for artificial inoculation of sweet cherry fruits. The isolate was obtained from naturally infected fruits of cv. Regina, during 2016, at Rimski Šančevi (45 $20^{\prime} \mathrm{N}$ and $19^{\circ} 50^{\prime}$ E, $80 \mathrm{~m}$ a.s.1.), Novi Sad, Serbia. The isolate belongs to the microbial collection of the Laboratory for diagnostic of pathogens, pests and weeds, Faculty of Agriculture, University of Novi Sad, Serbia. The isolate of Monilinia laxa used in this experiment was identified based on colony characteristics of cultures grown on PDA according to VAN LEEUWEN \& VAN KESTEREN [14]. For the trial purposes, the isolate of Monilinia laxa was grown on potato dextrose agar medium (PDA) for seven days, in dark at $23^{\circ} \mathrm{C} \pm 1^{\circ} \mathrm{C}$.

\section{Essential oil treatments}

The essential oil used in the study is $100 \%$ pure EO of wild oregano and it is commercially available and intended for human use (ingredients: carvacol $81.5 \%$, paracymen $3.8 \%$, thimol $0,7 \%$ ). Three application methods were used to apply the essential oil: 1) incorporation of $1 \mu 1$ of $5 \%$ water dilution of EO in inoculation site just before fruit inoculation; 2) exposing of inoculated fruits to vapor phase of EO, which was placed in Petri dish inside a plastic chamber with sweet cherry fruits at concentration of $0.08 \mu \mathrm{l} / \mathrm{cm}^{3}$ and $0.16 \mu \mathrm{l} / \mathrm{cm}^{3}$ of air during the entire trial period and 3 ) immersion of fruits in 5\% dilution of EO, for 10 seconds, just before the inoculation. 0,1\% Tween 80 (Sigma Adrich) was added during preparation of essential oil and water dilution. Before the application, the dilution was shaken for 30 seconds in order to obtain homogeneity.

\section{Virulence assay}

The experiment was conducted on the fruits of two sweet cherry cultivars, Regina and Karina, grafted on Gisela 5 rootstock. Trees were planted in 2012, at the planting density $4 \times 1.5 \mathrm{~m}$, situated at the Experimental field for fruit growing of the Faculty of Agriculture (Rimski Šančevi, $45^{\circ} 20^{\prime} \mathrm{N}$ and $19^{\circ} 50^{\prime} \mathrm{E}, 80 \mathrm{~m}$ a.s.1.), Novi Sad, Serbia. The fruits used in the experiment have following characteristics: Regina - fruit weight at harvest $14.8 \mathrm{~g}$; fruit diameter $30.0 \mathrm{~mm}$; soluble solids content $20.3 \%$ and titratable acidity $0.41 \%$, and Karina - fruit weight at harvest $12.8 \mathrm{~g}$; fruit diameter $28.7 \mathrm{~mm}$; soluble solids content $16.8 \%$ and titratable acidity $0.51 \%$. Booth, Regina and Karina are late ripening varieties and usually exposed to rainy weather during June (harvest period in Serbia) which can induce Monilinia sp. development. Fruits were surface - sterilized and injured with a sterile cork borer ( $\varnothing 4 \mathrm{~mm}$ and $3 \mathrm{~mm}$ deep). One quarter of total number of injured fruits was treated with the EO as presented in previous section (half by incorporation of EO in inoculation site and half by immersion of injured fruits in EO). Treated and untreated injured fruits were artificially inoculated with mycelium plugs ( $\varnothing 3 \mathrm{~mm}$ ) of Monilinia laxa isolate 
by putting one mycelium plug in each fruit injury. Each treatment was performed in triplicate with 50 fruits in the replicate.

Inoculated fruits were placed in disinfected, nonhermetically closed plastic chambers and half of the untreated fruits were exposed to two concentrations of volatile phase of EO in the chamber. The other half of untreated fruits placed in chambers remained untreated and was used as a positive control. Fruits inoculated with sterile PDA plugs were used as a negative control. Each treatment consisted of eighty fruits divided in four repetitions.

After EO treatment and inoculation, plastic chambers were divided in two identical groups. One group was stored at room temperature for five (cv. Karina) or six days (cv. Regina). The other group was stored in cold storage (normal atmosphere (NA), air temperature $2 \pm 1^{\circ} \mathrm{C}$, relative humidity $70 \%$ ) for 14 days, and was additionally incubated after storage at room temperature for five (cv. Karina) and six days (cv. Regina).

The diameter of necrotic lesions developed (mm) was measured every day during the storage period (room temperature and NA cold storage) and during additional incubation of NA stored fruits at room temperature. Necrosis development rate (NDR) (mm/day) was calculated by dividing necrosis diameter $(\mathrm{mm})$ by the duration of the observation period (days) for each of the observation points (every day of incubation at NA storage and at room temperature).

\section{Statistical analysis}

The obtained data were processed by ANOVA using statistical software STATISTICA 13 (StatSoft Inc., Tulsa, UK, USA) and significance of differences between different methods of application was tested using Duncan's multiple range test $(\mathrm{p} \leq 0.05)$.

\section{Results}

On fruits cv. Regina incubated under NA storage conditions (Figure 1) the first symptom was detected after 10 days in untreated control, after 11 days in treatment with lower concentration of vapor phase, and in 5\% incorporation treatment. In treatment with higher concentration of vapor phase, the first symptom was observed after one day of additional incubation at room temperature. Regardless of the concentration applied or the method of application, EO inhibited necrosis development on fruits during cold storage followed by the incubation at room temperature. After additional incubation at room temperature, significant statistical difference was observed between the necrosis diameter on untreated control and on fruits incorporated with EO. Also, the vapor phase showed significant inhibitory effect at both applied concentrations.

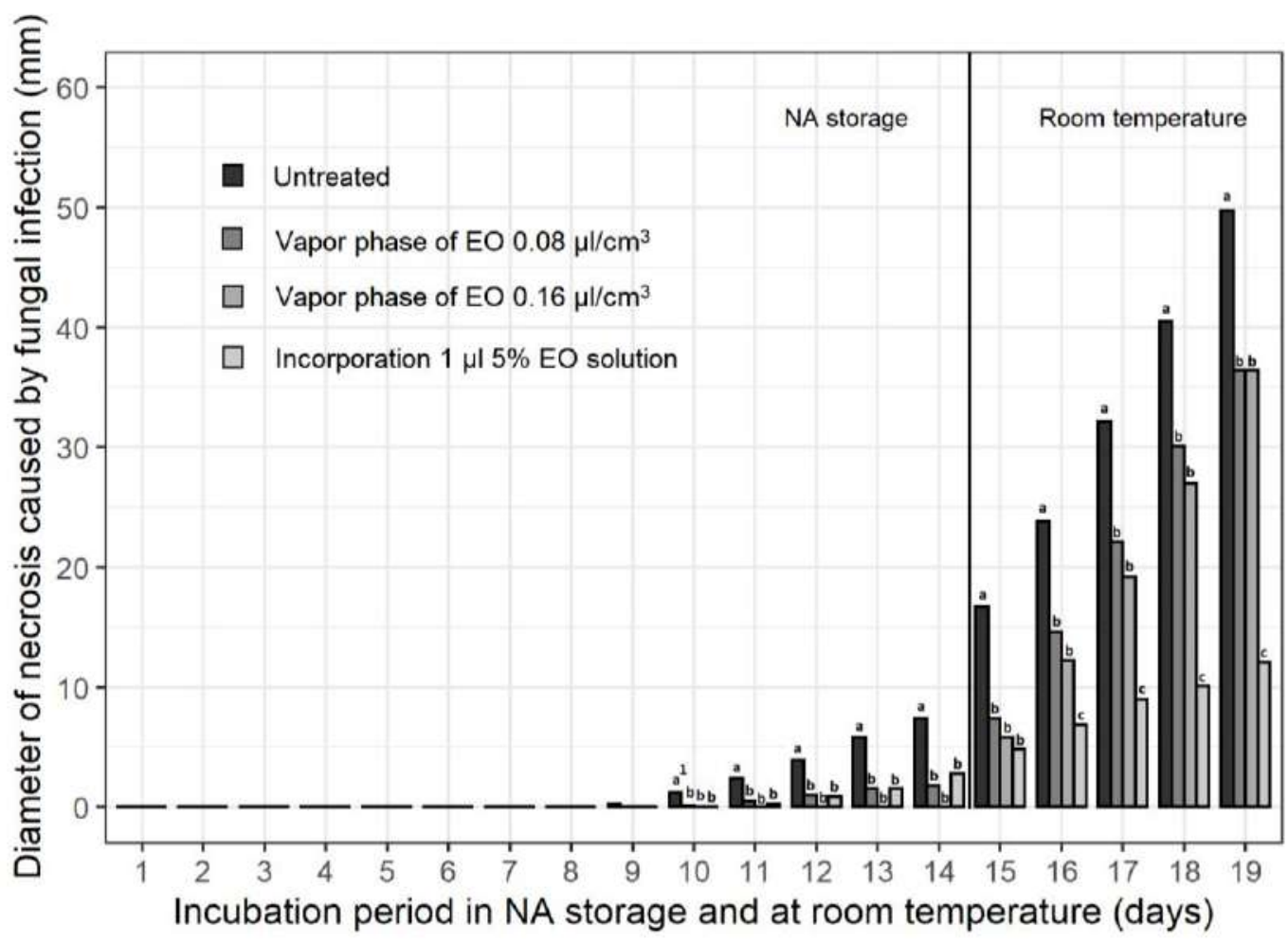

Figure 1. The diameter of necrosis caused by Monilinia laxa, on fruits of cv. Regina treated with wild oregano EO depending on the application method and EO concentration, during the cold storage under NA conditions and further incubation at room temperature.

${ }^{1}$ Bars marked with different letters point to significantly different values according to Duncan's multiple range test at $p \leq 0.05$ within a given period. 
On cv. Karina fruits, the first symptom was detected on the $5^{\text {th }}$ day in cold-storage, and the highest necrosis diameter was registered in the untreated control (Figure 2). The effects of the vapor phase of EO at both concentrations were the same until the $16^{\text {th }}$ day (14 days in cold storage under NA conditions and 2 days of additional incubation at room temperature). After that period, the effect of the vapor phase of EO at the lower concentration weakened. Significant differences were noted between the necrosis diameter of the untreated control and all other treatments at the end of incubation period at room temperature. The highest inhibitory effect of EO was achieved by the incorporation method.

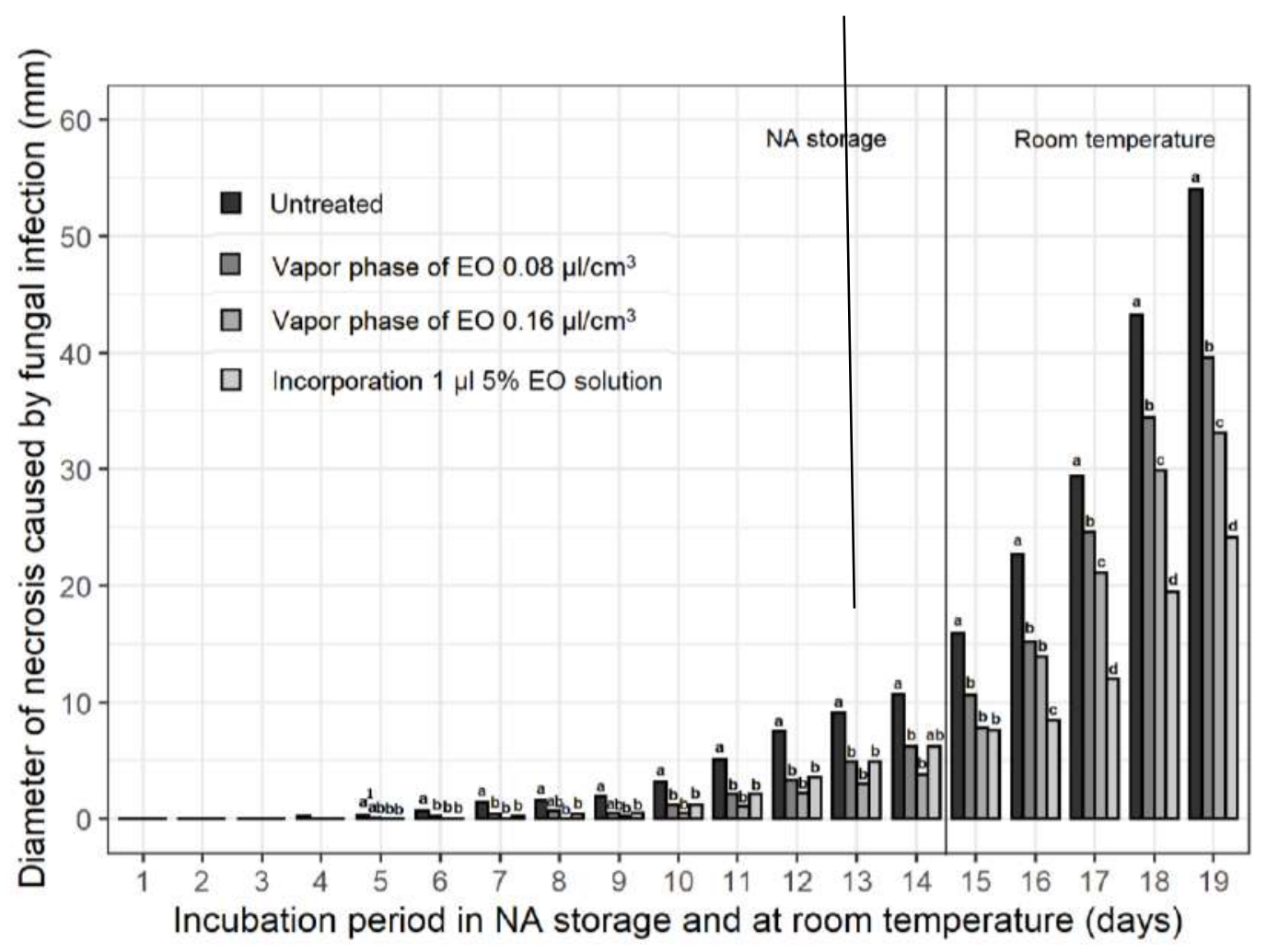

Figure 2. The diameter of necrosis caused by Monilinia laxa, on fruits of cv. Karina treated with wild oregano EO depending on the application method and EO concentration, during the cold storage under NA conditions and further incubation at room temperature.

${ }^{1}$ Bars marked with different letters point to significantly different values according to Duncan's multiple range test at $p \leq 0.05$ within a given period.

Development of necrosis on artificially inoculated sweet cherry fruits incubated at room temperature only is presented in Fig. 3. The incubation period lasted 6 days in cv. Regina, and 5 days in cv. Karina. In both cultivars at room temperature, the necrosis occurrence was first recorded on the second day of incubation, and the highest necrosis diameter was measured in the untreated control. EO showed inhibitory effect on the necrosis development regardless of the application method or the cultivar tested. The vapor phase of EO inhibited necrosis development regardless of the concentration applied, but the most effective method of EO application was the incorporation of $5 \%$ EO dilution. In cv. Karina, all fruits completely collapsed after 5 days.
Severe phytotoxicity on the fruit skin in both cultivars was observed on artificially inoculated fruits immersed in $5 \%$ dilution of EO, under both storage conditions.

NDR (mm/day) of artificially inoculated sweet cherry fruits of cv. Regina is presented in Fig. 4. NDR was variable during the observation period depending on the applied concentration of EO and the application method. During storage under NA conditions, NDR did not differ among the treatments. However, at the end of additional incubation at room temperature, the lowest NDR was recorded on fruits incorporated with $5 \%$ EO dilution, where NDR did not significantly change during the observation period. 


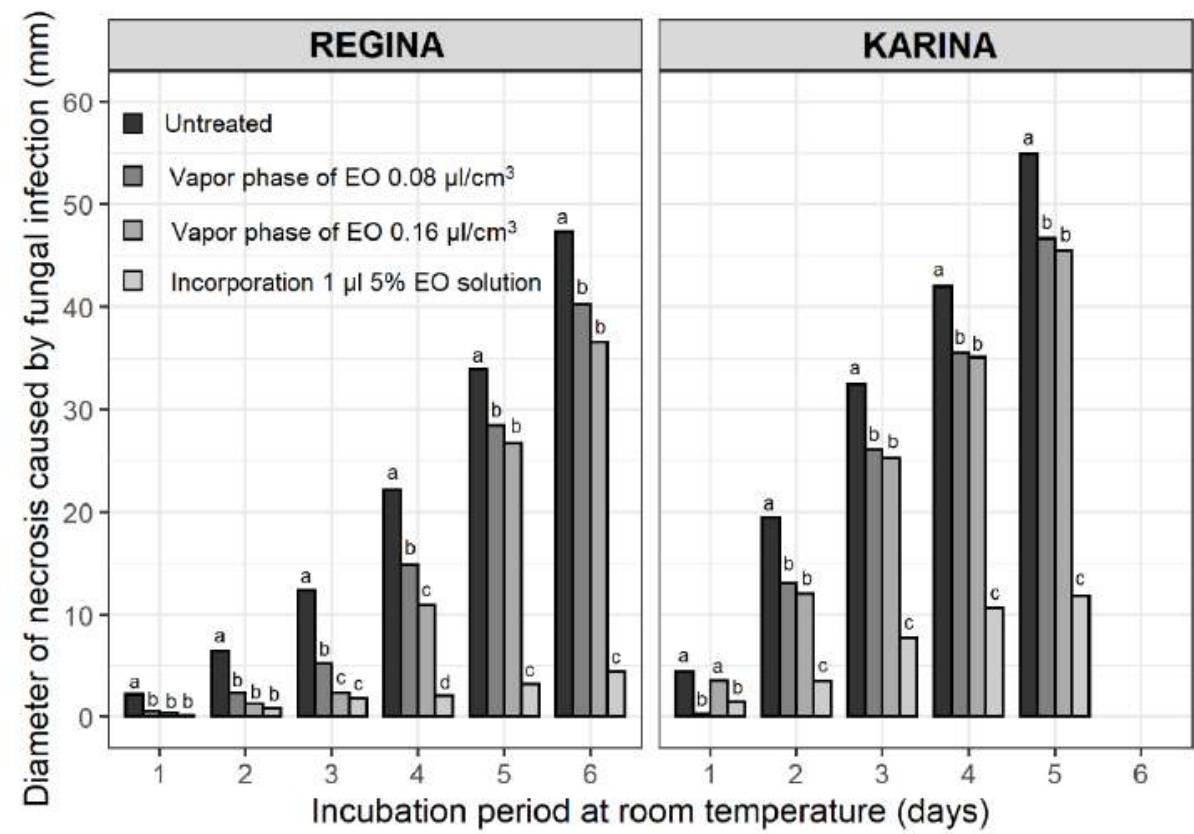

Figure 3. The diameter of necrosis caused by Monilinia laxa, on fruits of a) cv. Regina, and b) cv. Karina treated with wild oregano EO depending on the application method and EO concentration, at room temperature.

${ }^{1}$ Bars marked with different letters point to significantly different values according to Duncan's multiple range test at $p \leq 0.05$ within a given period for each cultivar separately.

NDR of fruits treated with vapor phase of EO and NDR of untreated fruits increased significantly on the first day of additional incubation period at room temperature.
On fruits treated by vapor phase of EO at lower concentration NDR decreased on the last day of additional incubation at room temperature.

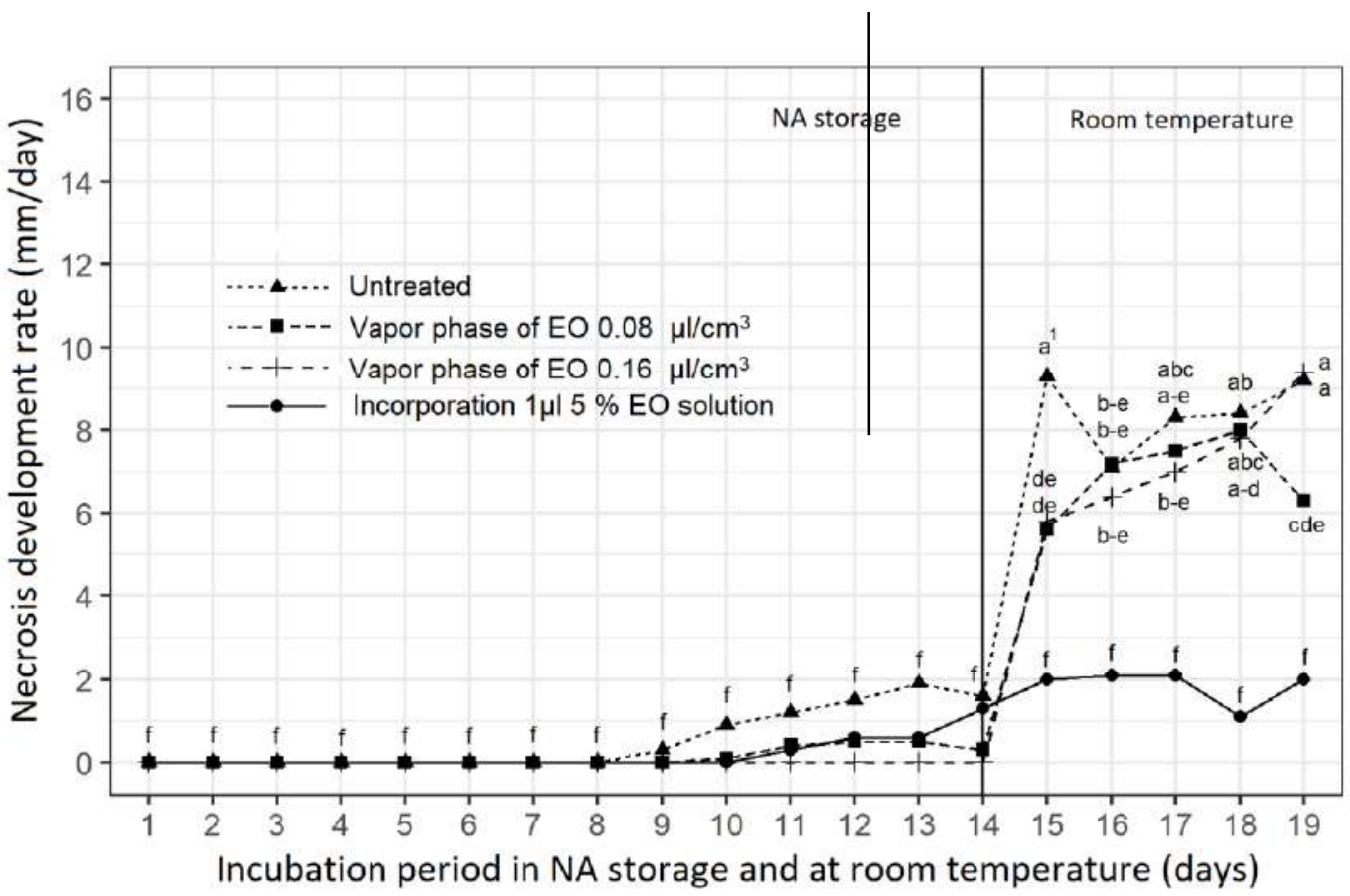

Figure 4. Necrosis development rate (NDR) caused by Monilinia laxa, on fruits of cv. Regina treated with wild oregano EO depending on the application method and EO concentration, during the cold storage under NA conditions and further incubation at room temperature.

${ }^{1}$ until $14^{\text {th }}$ no statistically significant differences between treatments were observed.

${ }^{2}$ Values marked with different letters are significantly different according to Duncan's multiple range test at $p \leq 0.05$ within a given period. 
There were no significant differences in NDRs among treatments during the 14-day period of cold-storage in cv. Karina Fig. 5. After fruits were placed at room temperature NDRs increased in all treatments, except for the incorporation method. Regardless the method of application and the concentration, EO was efficient in decreasing the NDR at the end of observation period at room temperature. During two last days of the incubation period at room temperature, all EO treatments significantly reduced NDR compared to the untreated control.

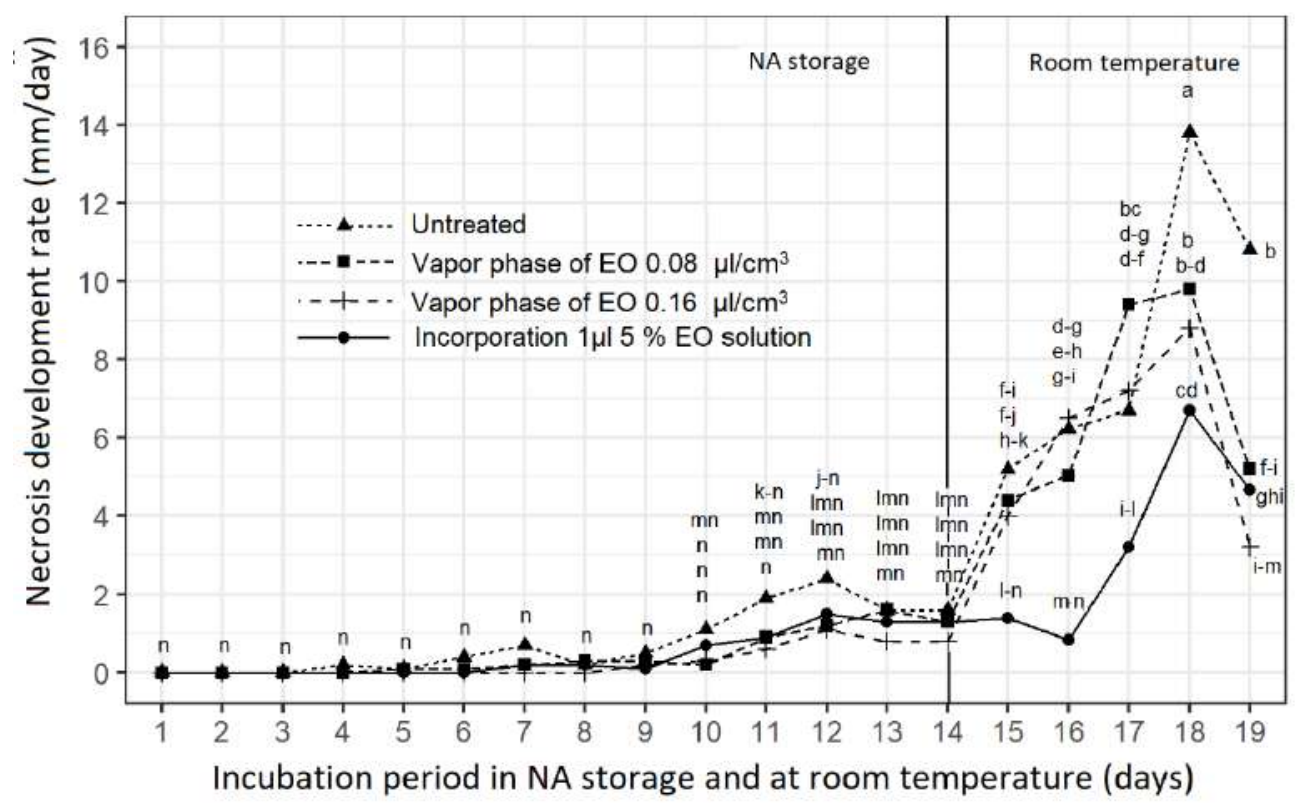

Figure 5. Necrosis development rate (NDR) caused by Monilinia laxa, on fruits of cv. Karina treated with wild oregano EO depending on the application method and EO concentration, during the cold storage under NA conditions and further incubation at room temperature.

${ }^{1}$ Until $9^{\text {th }}$ no statistically significant differences between treatments were observed.

${ }^{2}$ Values marked with different letters are significantly different according to Duncan's multiple range test at $p \leq 0.05$ within a given period.

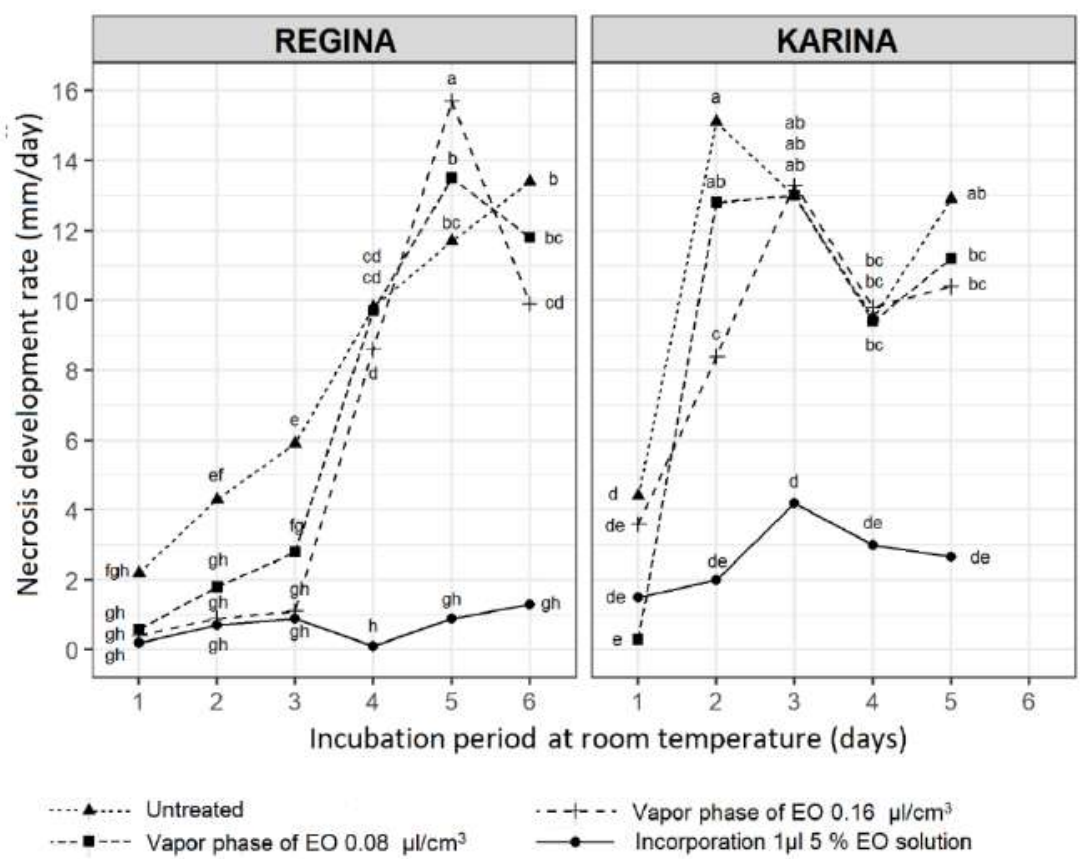

Figure 6. Necrosis development rate (NDR) caused by Monilinia laxa, on fruits of a) cv. Regina, and b) cv. Karina treated with wild oregano EO depending on the application method and EO concentration, at room temperature.

${ }^{1}$ Values marked with different letters are significantly different according to Duncan's multiple range test at $p \leq 0.05$ within a given period for each cultivar separately. 
NDR on fruits of cv. Regina stored at room temperature only, ranged between 2.2 and $13.4 \mathrm{~mm}$ per day in the untreated control. In control, NDR continuously increased starting from the first day of incubation, while in EO treated fruits NDR did not significantly change during the first three days of incubation at room temperature. On day $4^{\text {th }}$ and $5^{\text {th }}$ day, NDR in fruits treated with the vapor phase EO (regardless the concentration applied) was at the same level as in the control fruits. On the last day of incubation at room temperature, the vapor phase applied at the higher concentration decreased NDR compared to the control. Method of incorporation of 5\% EO was the most effective in decreasing NDR, keeping it at low rate during the whole incubation period.

Vapor phase of EO at lower concentration did not affect NDR relative to the control at the end of the observation period in $\mathrm{cv}$. Karina. The method of incorporation of $5 \%$ EO solution was efficient in decreasing NDR throughout entire incubation period relative to the control.

\section{Discussion}

Sweet cherry losses in storage caused by Monilinia sp. can be higher than losses during vegetation period (BØRVE \& al [15]). Also, LARENA \& et al [16] stated that peach losses caused by Monilinia sp. during storage period can reach up to $80-85 \%$.

According to GATTO \& al. [17] growth of M. fructicola in vitro and in vivo, can be significantly decreased by lowering the storage temperature down to $0^{\circ} \mathrm{C}$. However, M. laxa was able to continue its development even at temperatures below $-4^{\circ} \mathrm{C}$ (TIAN \& BERTOLINI, [18]). Although infection and development of symptoms occur in a wide temperature range $\left(0-35^{\circ} \mathrm{C}\right)$, the optimal temperature for development of Monilinia sp. is $24^{\circ} \mathrm{C}$, while the infection is weaker at lower temperatures $\left(0-5^{\circ} \mathrm{C}\right)$ (CASALS \& al [19]). Cultivar characteristics are significant factor and considerably affect the occurrence of Monilinia laxa on fruits. Thus, in cv. Regina, the first symptom on fruits was registered after ten days in NA storage, while in cv. Karina after five days only. According to SALATO \& al. [20], fruit firmness is one of the most important parameters which affects necrosis diameter and necrosis development rate on stored fruits. Higher fruits firmness contributes to better quality preservation and reduces the development of fungal decay (EINHORN \& al [21]). Regina has a higher firmness compared to Karina (RADIČEVIĆ [22]), so it can be assumed that cv. Regina might be more resistant to fungal decay.

It is confirmed that EO of wild oregano has antifungal activity against Monilinia sp. LOPEZ REYES \& al. [23] reported that duration of storage period significantly affects inhibitory effect of EO. They also observed that after 15 days in NA storage efficacy of EO started to decrease. Therefore, the use of EO is recommended only for short storage period, and the treatment should be repeated if storage period is prolonged. In the present research, EO decreased necrosis diameter until the end of the experiment. However, due to different methods of application, EO exhibited variable inhibitory effect on this pathogen. Among the methods tested, the incorporation of EO into fruits exhibited the highest efficacy in inhibiting necrosis development during incubation at room temperature, while the vapor phase was far less efficient in both cultivars.

The concentration of EO applied is not considered to be the key factor in inhibition of disease development in storage (BOSQUEZ-MOLINA \& al [24]), which is confirmed by the present research. According to LOPEZREYES \& al. [25], the inhibitory effect of different EOs on M. laxa in artificially inoculated fruits was consistent regardless the concentration applied within the range between $1 \%$ and $10 \%$. Wild oregano EO showed the same effect in controlling the development of Monilinia laxa in nectarine cv. Nectaross, regardless the concentration, while on cv. Big Top a higher efficacy was recorded when a higher EO concentration was applied. Such was the case with cold stored fruits of sweet cherry cv. Regina additionally incubated at room temperature, where the vapor phase of EO applied at the concentration of $0.16 \mu \mathrm{l}$ per $\mathrm{cm}^{3}$ exhibited the higher inhibitory effect on Monilinia laxa compared to the lower concentration of $0.08 \mu \mathrm{l}$ per $\mathrm{cm}^{3}$. In cv. Karina the differences between two concentrations of EO applied were insignificant. In their study CAROVIĆ-STANKO \& al. [26] found out that the effectiveness of EO is highly dependent on their composition and evaporation.

According to TARLANOVIĆ \& al. [27] wild oregano EO applied as vapor phase $\left(0.16 \mu \mathrm{l}\right.$ per $\left.\mathrm{cm}^{3}\right)$ exhibited an inhibitory effect on Fusarium avenaceum and Alternaria alteranata in NA storage but caused phytotoxic changes on apple fruit skin. The severe phytotoxicity was observed, thus this treatment was excluded from the results. In this paper, severe phytotoxicity was observed on the fruit skin on artificially inoculated fruits immersed in 5\% dilution of EO, while in vapor phase treatment skin damage was not observed. Therefore, it can be concluded that phytotoxicity is very likely to occur and it is necessary to be very careful when planning the method, concentrations and exposure period for EO application. BOSQUEZ-MOLINA \& al. [24] reported that occurrence of papaya fruit rot caused by Colletotrichum gleosporioides decreased up to $50 \%$ when fruits have been immersed in the solution of incense oil (concentration $0-12 \%$ ). However, in the present research, a severe phytotoxicity was observed when fruits were immersed in 5\% EO solution. According to these findings, in the further research it is necessary to investigate the possibility of application of lower concentrations of EO solution by immersion.

Necrosis development rate (NDR) of Monilinialaxa on artificially inoculated fruits varies considerably 
depending on cultivar characteristics and storage temperature. Thus, NDR during cold-storage was significantly lower compared to NDR during incubation period at room temperature. HRUSTIC [28] reported that the colony growth rate (CGR) of different Monilinia species, as well as different isolates, varied considerably. CGR of Monilinia laxa on PDA medium, at $24^{\circ} \mathrm{C}$ varied considerably depending on isolate characteristics. The same author found that $M$. fructigena had lower NDR than M. laxa. M. fructicola had the highest CGR on PDA medium. According to ZHU \& al. [29], NDR on nectarine fruits artificially inoculated with different Monilinia spp. isolates, stored at $24{ }^{\circ} \mathrm{C}$ was $23.0-24.5 \mathrm{~mm}$ per day, while on apricot fruits it was $28.6-33.9 \mathrm{~mm}$ per day.

\section{Conclusion}

Inhibitory effect of wild oregano EO on Monilinia rot development on stored sweet cherry fruits Regina and Karina largely depends on the method of application and concentration. Method of application that showed the highest inhibitory effect on Monilinialaxa was incorporation of EO, but this treatment is not practically applicable. Vapor phase also exhibits satisfactory effect, while immersing of fruits in EO dilution caused phytotoxic changes on the fruit skin. Therefore, it is surely clear that use of wild oregano EO is a promising method for control of sweet cherry fruit decay. It is necessary to expand this research and find the most suitable method and concentration of EO that will be practically applicable, and commercially viable.

\section{Acknowledgements}

This research was supported and funded by the Ministry of Education, Science and Technological Development of Republic of Serbia as one of the research topics of the project "Selection of sweet and sour cherry dwarfing rootstocks and development of intensive cultivation technology based on sustainable agriculture principles" (TR31038), and project "Development of integrated management of harmful organisms in plant production in order to overcome resistance and to improve food quality and safety" (III46008).

\section{Conflict of Interest disclosure}

There are no known conflicts of interest in the publication of this article. The manuscript was read and approved by all authors.

\section{Compliance with ethical standards}

Any aspect of the work covered in this manuscript has been conducted with the ethical approval of all relevant bodies and that such approvals are acknowledged within the manuscript.

\section{References}

1. A.L. JIANG, S.P. TIAN, Y. XU. Effect of controlled atmospheres with high-O2 and high $\mathrm{CO}_{2}$ concentrations on postharvest physiology and storability of 'Napoleon' sweet cherry. Acta Bot. Sin., 44: 925-930 (2002).

2. E. DZIEDZIC, J. BLASCZYC, E. KACMARCZYC. Influence of rootstocks and storage conditions on the quality of sweet cherry fruits 'Regina'. Acta Sci PolHortoru, 15: 119-131 (2016).

3. E. BAL. Effects of essential oil treatments combined with hot water treatment on improving the postharvest life of sweet cherry. Fruits, 67: 285-291 (2012).

4. S.J. ZHU. Non-chemical approaches to decay control in postharvest fruit. In B. Noureddine \& S Norio (Eds.): Advances in postharvest technologies for horticultural crops, pp. 297-313. Trivandrum, India: Research Signpost. (2006).

5. W.J. JANISIEWICZ, L. KORSTEN. Biological control of postharvest diseases of fruits. Annu Rev Phytopathol, 40: 411-441 (2002).

6. G. ROMANAZZI, F. NIGRO, A. IPPOLITO, M. SALERNO. Effect of short hypobaric treatments on postharvest rots of sweet cherries, strawberries and table grapes. Postharvest Biol Technol, 22: 1, 1-6 (2001).

7. E. FELIZIANI, M. SANTINI, L. LANDI, G. ROMANAZZI. Pre- and postharvest treatment with alternatives to synthetic fungicides to control postharvest decay of sweet cherry. Postharvest Biol Technol, 78: 133-138 (2013).

8. K.J. BRENT, D.W.HOLOMON. Fungicide resistance in crop pathogens: How can it be managed? FRAC Monograph No. 1 (Second Revised Edition), pp 7-14. Brussels: Global Crop Protection Federation (2007).

9. M. SERRANO, D. MARTINEZ-ROMERO, S. CASTILLO, F. GUILLEN, D. VALERO. The use of natural antifungal compounds improves the beneficial effect of MAP in sweet cherry storage. Innov Food Sci Emerg Techol, 6: 115-123 (2005).

10. V.K. JUNEJA, D.W. THAYER. Irradiation and other physical based control strategies for foodborne pathogens. In: Wilson, C.L., Droby, S. (Eds.), Microbial Food Contamination, pp. 171-186. CRC Press, Boca Raton, DC, USA (2001).

11. A. IPPOLITO, F. NIGRO. Natural antimicrobials in postharvest storage of fresh fruit and vegetables. In: Roller, S. (Ed.), Natural Antimicrobials for the Minimal Processing of Foods, pp. 201-234. CRC Press, Boca Raton, DC, USA (2003).

12. D.J. DAFERERA, B.N. ZIOGAS M.G. POLISSIOU. The effectiveness of plant essential oils on the growth of Botrytis cinerea, Fusarium sp. and Clavibacter michiganensis subsp. michiganensis. Crop Prot, 22: 39-44 (2003). 
13. L. BARRERA-NECHA, S. BAUTISTA-BANOS, H. FLORES-MOCTEZUMA, A. ESTUDILO. Efficacy of essential oils on the conidial germination, growth of Colletotrichum gleosporoides (Penz.) Penz. i Sacc. And control of postharvest diseases in papaya (Carica papaya L.). Plant Pathol. J., 7: 174-178 (2008).

14. G.C.M. VAN LEEUWEN, H.A. VAN KESTEREN. Delineation of the three brown rot fungi of fruit crops (Monilinia spp.) on the basis of quantitative characteristics. Can J Bot, 76: 2042-2050 (1998).

15. J. BØRVE, A. STENSVAND. Use of a plastic rain shield reduces fruit decay and need for fungicides in sweet cherry. Plant Dis, 87: 523-528 (2003).

16. I. LARENA, R.A. DE CAL TORRES, M. LIÑÁN, P. MELGAREJO, P. DOMENICHINI, A. BELLINI, J.F. MANDRIN, X. OCHOA DE ERIBE, J. USALL. Biological control of postharvest brown rot (Monilinia spp.) of peaches by field applications of Epicoccum nigrum. Biol Control, 32: 305-310 (2005).

17. M.A. GATTO, L. SERGIO, A. IPPOLITO, D. DI VENERE. Phenolic extracts from wild edible plants to control postharvest diseases of sweet cherry fruit. Postahvarvest Biol Technol, 120: 180-187 (2016).

18. S.P. TIAN, P. BERTOLINI. Effect of temperature during conidial formation of Monilinia laxa on conidial size, germination and infection of stored nectarines. J Phytopathol, 147: 635-641 (1999).

19. C. CASALS, I. VIÑAS, R. TORRES, C. GRIERA, J. USALL. Effect of temperature and water activity on in vitro germination of Monilinia spp. J Appl Microbiol, 108: 47-54 (2010).

20. S.G. SALATO, M.A.N. PONCE, D.M. RAFFO, R.A. VICENTE, C.A. STORTZ. Developmental changes in cell wall polysaccharides from sweet cherry (Prunus avium L.) cultivars with contrasting firmness. Postharvest Biol Technol, 84: 66-73 (2013).

21. T.C. EINHORN, Y. WANG, J. TURNER. Sweet cherry fruit firmness and postharvest quality of latematuring cultivars are improved with low-rate, single applications of gibberellic acid. Hortscience, 48: 10101017 (2013).

22. S. RADIČEVIĆ. Fertilization biology and pomological properties of newly introduced sweet cherry (Prunus avium L.), Dissertation. University of Belgrade, Faculty of Agriculture (2013).

23. J.G., LOPEZ-REYES, D., SPADARO, M.L. GULLINO, A. GARIBALDI. Efficacy of plant essential oils on postharvest control of rot caused by fungi on four cultivars of apples in vivo. Flavour and Fragr J, 25: 171-177 (2010).

24. E. BOSQUEZ-MOLINA, E. RONQUILLO DEJESUS, S. BAUTISTA-BANOS, J. VERDE-CALVO, J. MORALES-LOPEZ. Inhibitory effect of essential oils against Colletotrichum gleosporoides and Rhizopus stolonifer in stored papaya fruit and their possible application in coatings. Postharvest Biol. Technol., 57: 132-137 (2010).

25. J.G. LOPEZ-REYES, D. SPADARO, A. PRELLE, A. GARIBALDI, M.L. GULINO. Efficacy of plant essential oils control of rots caused by fungi on different stone fruits in vivo. J Food Prot, 76: 631-639 (2013).

26. K. CAROVIĆ-STANKO, G. FRUK, Z. SATOVIĆ, D. IVIĆ, O. POLITEO, Z. SEVER, M. GRDIŠA, F. STRIKIĆ, T. JEMRIĆ. Effects of Ocimum spp. essential oil on Monilinia laxa in vitro. J Essent Oil Res, 25: 143-148 (2013).

27. J. TARLANOVIĆ, M. GRAHOVAC, B. MILIĆ, N. MAGAZIN, Z. KESEROVIĆ, M. PETREŠ, M. MIODRAGOVIĆ. Effects of storage conditions on virulence of Fusarium avenaceum and Alternaria altrenata on apple fruits. J Phytopathol, 165: 595-601 (2017).

28. J. HRUSTIĆ. Characterization of Monilinia species pathogens of stone fruits in Serbia and sensitivity to fungicides, Dissertation. University of Belgrade, Faculty of Agriculture (2014)

29. X. ZHU, X. CHEN, L. GUO. Population structure of brown rot fungi on stone fruits in China. Plant Dis, 95: 1284-1291 (2011). 